\title{
The Study of The Architectural Characteristics of Rumah Godong of The Anak Dalam Tribe in Sumatra
}

Muhammar Khamdevi

e-mail:m.khamdevi@gmail.com

Prodi Arsitektur Universitas Matana

\section{Abstract}

The Anak Dalam tribe (Suku Anak Dalam or Suku Kubu or Orang Rimba) is one of the tribes in Central Sumatra. This tribe still lives simply and depends on nature in the forest. This tribe has its own very simple traditional house, which indicates the earliest vernacular houses in Sumatra, especially in the "Malay" or Malayic-speaking areas of Central Sumatra. However, a comprehensive study of the architectural characteristics of Rumah Godong is still not well available. What are the characteristics of Rumah Godong? Suku Anak Dalam This research uses a qualitative method approach to descriptively analyze case objects in the field. The results of this study provide a description of the architectural characteristics of Rumah Godong.

Keywords : traditional house, suku anak dalam, rumah godong, architectural characteristics, vernacular house

\begin{abstract}
Abstrak
Suku Anak Dalam (Suku Kubu atau Orang Rimba) adalah salah satu suku yang berada di wilayah Sumatera Tengah. Suku ini masih hidup secara sederhana dan bergantung dengan alam di hutan. Suku ini memiliki rumah tradisionalnya sendiri yang sangat sederhana, yang mengindikasikan rumah vernacular awal di Sumatera, terutama di wilayah "Melayu" atau penutur Malayic di Sumatera Tengah. Namun kajian secara komprehensif mengenai karakteristik arsitektur Rumah Godong masih belum tersedia dengan baik. Bagaimanakah karakteristik Rumah Godong Suku Anak Dalam? Penelitian ini menggunakan pendekatan metode kualitatif untuk menganalisis objek kasus secara langsung di lapangan secara deskriptif. Hasil penelitian ini memberikan deskripsi tentang karakteristik arsitektural Rumah Godong.
\end{abstract}

Kata Kunci : rumah tradisional, suku anak dalam, rumah godong, karakteristik arsitektur, rumah vernakular

\section{Introduction}

The Suku Anak Dalam or often referred to as Suku Kubu or Orang Rimba or Orang Ulu. Kubu itself means fort or hamlet. They live nomadic life depending on the forest and still carry out hunting and gathering activities. They are scattered in the Dharmsraya area in West Sumatra, Bukit Tigapuluh and Bukit Duabelas in Jambi, the Musi Rawas watershed, and the Kikim watershed in South Sumatra. Their clothes were loincloths that were once made of bark but now made of cotton. This tribe is led by a Temenggung and oversees the groups under him headed by a Patih. 
The Study of The Architectural Characteristics of Rumah Godong of The Anak Dalam Tribe in Sumatra

Patih oversees small groups from each family headed by Tengganai (Prasetijo, 2011, Qulub, 2016 and Arios et al., 2019).

This tribe is widely regarded as Proto-Malay. However, this is actually not correct, because the socalled Proto-Malays were the first inhabitants on the island of Sumatra with Austroasiatic-Negrito characteristics, such as those found in the interior of Peninsular Malaysia, Aslian. So the Suku Anak Dalam is actually still a family with the tribes in Central Sumatra, especially in terms of language and culture, Malay or Deutro-Malay.

In addition, the territory of the Suku Anak Dalam was under the leadership of the Sriwijaya Kingdom, Malayupura Kingdom, Pagaruyung Kingdom, Johor-Riau-Linggau Sultanate, and JambiPalembang Sultanate. This can be seen in the leadership system for the mention of TemenggungPatih-Tengganai which indicates the influence of the Kedatuan and Panghulu System (SriwijayaMalayupura-Pagaruyung), and the social system in the form of Batin or Kalbu which indicates the influence of the Kebatinan System, which is very commonly used by Orang Laut and has spread to the east coast of Sumatra, Jambi, and Palembang which are the territories of the Sultanate of Johor-Riau. The kinship system tends to be matrilineal called semende, with the in-laws' family called semendo.

Table 1. Numbers in Sakai and Minangkabau languages (Source: Khamdevi: 2016-2021)

\begin{tabular}{cccc}
\hline Numbers & Suku Anak Dalam & Minangkabau & Jambi \\
\hline One & Slai/ Ciek/ Sikuk & Ciek/ Aso & Sikok \\
\hline Two & Dua & Duo & Duo \\
\hline Three & Tiga & Tigo & Tigo \\
\hline Four & Mpat & Ampek & Empat \\
\hline Five & Lima & Limo & Limo \\
\hline Six & Nom & Anam & Enam \\
\hline Seven & Tujoh & Tujuah & Lapan \\
\hline Eight & Delapan & Sa-)Lapan & Sembilan \\
\hline Nine & Sembilan & Sambilan & Sepolo \\
\hline Ten & Spuloh & Sapuluah &
\end{tabular}

The traditional house called "Rumah Godong" reminds us of "Rumah Gadang" in West Sumatra and "Rumah Godang" in Riau, and "Rumah Gedang" in Hulu Batanghari Jambi. Rumah Godong itself has not been studied properly comprehensively and architecturally. Therefore this research was conducted. What are the Architectural Characteristics of the Suku Anak Dalam's house?

\section{Research Method}

In reviewing the architectural characteristics of the Rumah Godong, qualitative methods were used. The data was obtained in the field through observation and interviews. The samples were selected purposively (Sugiyono, 2012). These data were then analyzed using the theory of architectural characteristics, namely spatial systems, physical systems and figural configurations, and style systems (Habraken, 1988). 
Due to the spread of the Suku Anak Dalam to several provinces in Sumatra and also based on the consideration of the authenticity of the Rumah Godong, it was decided that the research was focused on the location of the Air Hitam sub-district in Sarolangun. The research was carried out directly in the field with permission from the Bukit Tigahpuluh National Park and Bukit Duabelas National Park, and was accompanied by KKI Warsi and one of the leaders of the Suku Anak Dalam there.

\section{Result and Discussion}

The traditional house architecture of the Suku Anak Dalam tribe can be divided into several types, such as:

1. Bolalapion, which functions as a temporary shelter, is open, has a mat (mat), with two pillars to support the roof.

2. Sengsudungon, which functions as a shelter for temporary overnight stays to travel far to hunt or gather (genah kemaloman), open, with wooden slats on top of two main logs, and four pillars to support the roof.

3. Rumah di Tanoh, which serves as a shelter for a long time, is open and can be closed, has a wooden slat floor, and has four pillars to support the roof. There is a division of space between the Wife and Husband rooms, where the Wife's room is lower. The children will be made a building next to it.

4. Rumah Godong, which serves as a permanent residence, even semi-permanent.

5. Rumah Tanoh Peranokon, a house in Tanoh which is devoted to a place for women who are about to give birth.

6. Bale Berhatop, which serves as a place for traditional ceremonies.
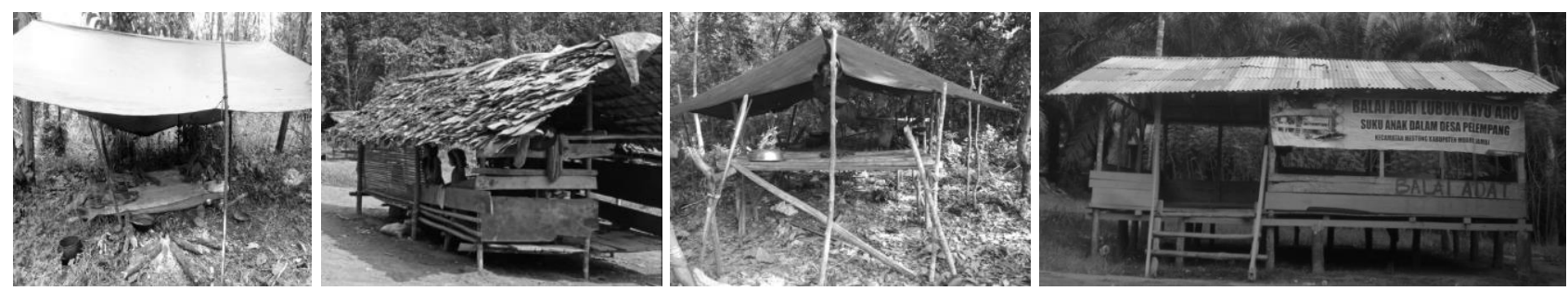

Figure 1. Suku Anaka Dalam's building types (from top-left to bottm-right): Bolalapion, Sengsudungon, Rumah di Tanoh, and Bale Berhatop

(Source: Khamdevi: 2016-2020)

Rumah Godong is inhabited by a nuclear family; father (Bepak), mother (Induk), and child (Anok). In simple terms, this house consists of nine posts (Tonggak) that divide the space into four parts, which measure six cubits (about three meters) to the back and eight to ten cubits (about four to five meters) to the sides. Each room is marked by a wooden stick on the floor. The post in the middle is the main pillar (Tiang Tuo). In the next development, this house can be added to the left side into twelve posts which divide the room into six parts. The main pillar is to the right of the center of the building. If there is not enough space for the children, they will build a hut adjacent to the main house, where the cottage for men is called Kekulupon and for women it is called Keupikon. The orientation of this house is usually determined by the shaman (Malim), in which the preferred direction is towards the river or sunrise. 

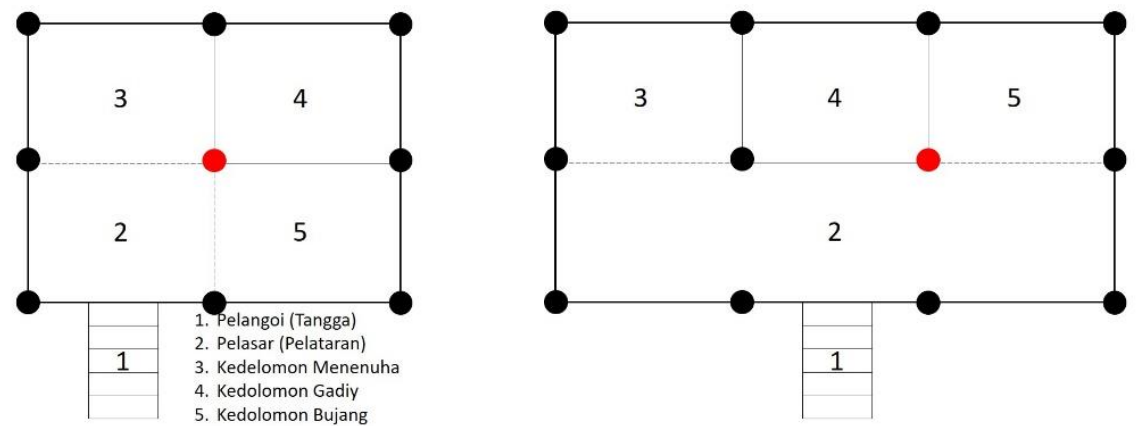

Figure 2. Rumah Godong's Floorplan

(Source: Khamdevi: 2021)

Entering this house we climb the stair (Pelangoi) which is located on the left, with a total of five steps. Then we enter the front room called the Pelasar to receive guests from the closest family and to serve as the core family room, which has a lower floor height than the bedrooms. Behind it is the parents' bedroom (Kelelomon Menenuha) which is side by side with the daughter's bedroom (Betino) called Kedelomon Gadiy or Budak Lapay, the floor is lower than the other rooms, and the room is covered with a wall made of woven leaves or bark (now with cloth, tarpaulin or wooden planks). In front of the house, there is a boy's bedroom (Jenton) called Kedelomon Budak Bujang. Above the house, there is an attic room called Loteng, which functions as a place to store goods and produce. While the cooking area in the form of a kitchen is outside the house building.
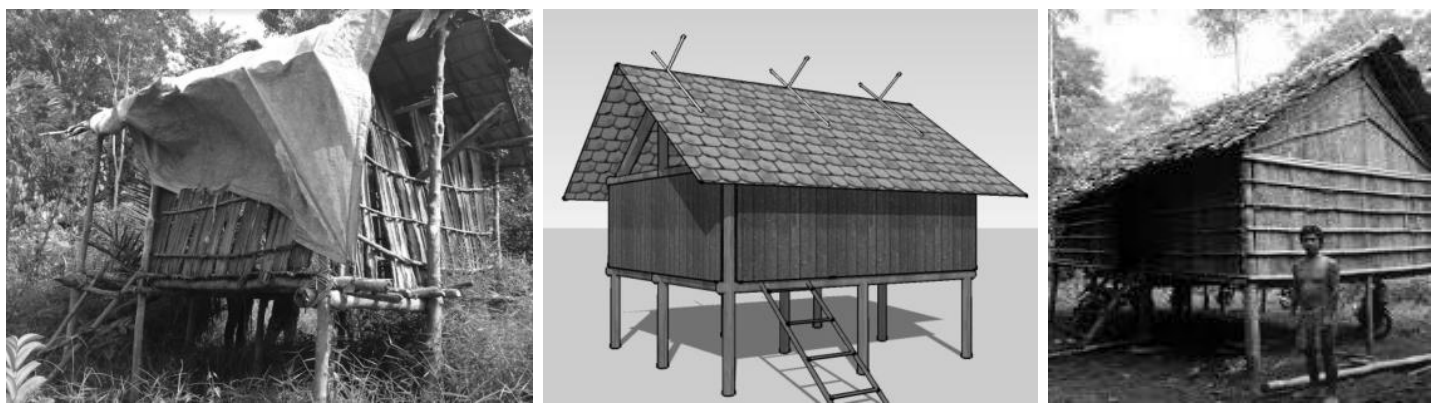

Figure 3. Rumah Godong's Appearance

(Source: Khamdevi: 2016-2021)

The posts of this house, including Tiang Tuo, are made of calf-sized wood from the tree of Buah Bunto, Meranti, Tamui Tengkerawo, or Plomo Ikan. The walls are made of the tree bark of Mesuai, Belahbayon, or Dukuh, commonly called Gelenggang. The floor is called Ambion which is made of bark similar to the walls. The roof is called Hatop, which is usually made of Benal leaves or Serdang leaves which consists of two layers and folds. The material is connected in the form of rattan bonds. The roof is also held or locked by a wooden or bamboo cross on it. The structure of this house can be seen in Figure 4. 


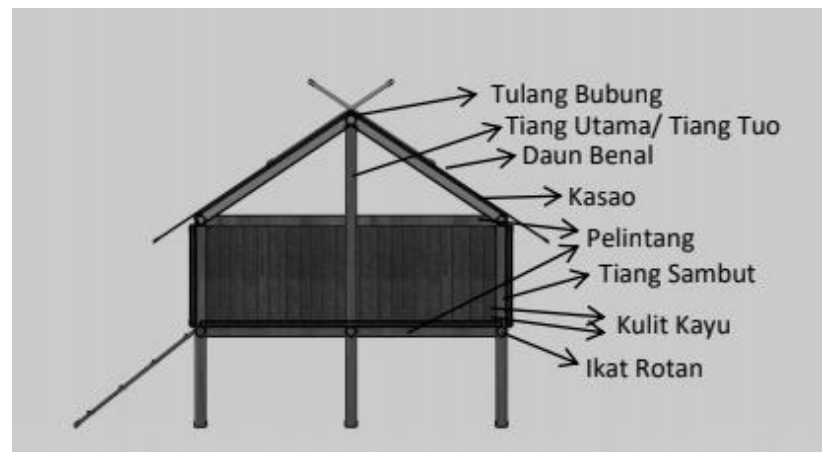

Figure 4. Rumah Godong's Section and Structure

(Source: Khamdevi: 2021)

This house gable roof type, wherein the Central Sumatra region it is often referred to as the Lipat Kajang. On the roof, some wooden crosses also function to hold the roof covering. The house posts consist of nine to twelve posts, where the post in the middle-right is the main post (Tiang Tuo). The opening of this house is only a front door and there are no windows. Natural air and light enter through the walls of the bark. The ladder has five steps.

\section{Conclusion}

The results of this study show the characteristics of Rumah Godong in Sumatra. Rumah Godong is similar to the houses of the tribes in Sumatra (Malay). The following is table 5.1 conclusions from this study. The results of this conclusion are expected to be a guideline to preserve the Rumah Godong.

Table 2. Rumah Godong's Characteristics (Source: Khamdevi: 2021)

\begin{tabular}{|c|c|c|}
\hline \multicolumn{3}{|l|}{ Architectural Characteristics } \\
\hline \multirow[t]{3}{*}{ Spatial System } & Space Pattern & Pelangoi > Pelasar > Kedelomon \\
\hline & Orientation & River or Sunrise \\
\hline & Hierarchy & Public $>$ Semi Private $>$ Private \\
\hline \multirow{4}{*}{ Physical System \& Figural Quality } & Physical form & Transverse square buiding \\
\hline & & Gable roof \\
\hline & Materials & Bark Wall, Wooden Poles, Leaf Roof, Rattan Tie \\
\hline & Space Barrier & Bark Wall or Woven Leaves \\
\hline \multirow[t]{7}{*}{ Stylistic System } & Roof & Lipat Kajang \\
\hline & & Wooden crosses \\
\hline & Column & $9-12$ post \\
\hline & & 1 main post (Tiang Tuo) \\
\hline & Openings & Rattan Tied Bark Door \\
\hline & & No windows, but porous walls between the bark \\
\hline & Stairs & Odd Number of Stairs (usually 5) \\
\hline
\end{tabular}

\section{References}

Arios, R. L. et al. (2019). Suku Anak Dalam (SAD) Di Kabupaten Dharmasraya Sumatera Barat. Padang: Balai Pelestarian Nilai Budaya Sumatera Barat.

Habraken, N. John (1988). Type as Social Agreement. Seoul: Asian Congress of Architect.

Prasetijo, A. (2011). Serah jajah dan perlawanan yang tersisa: Etnografi orang rimba di Jambi. Jakarta : Wedatama Widya Sastra. 
The Study of The Architectural Characteristics of Rumah Godong of The Anak Dalam Tribe in Sumatra

Qulub, S. T. (2016). Konstruksi Ruang Gender Pada Rumah Orang Rimba. Jurnal Musawa Vol. 15 No. 1. Yogyakarta: UIN Sunan Kalijaga.

Sugiyono (2012). Metode Penelitian Kuantitatif Kualitatif dan R \& D. Bandung: Alfabeta. 